\title{
The Changes of Mangrove Area in Pati Regency of the Year 2011 - 2015 and Their Impact Analysis: A Literature Review
}

\author{
Achmad Nur Prihantoro ${ }^{1 *}$, Sutrisno Anggoro², and Fuad Muhammad ${ }^{3}$ \\ ${ }^{1}$ Master Program of Environmental Science, School of Postgraduate Studies, Diponegoro University, Semarang - Indonesia \\ ${ }^{2}$ Department of Aquatic Resources, Faculty of Fisheries and Marine Sciences, Diponegoro University, Semarang - Indonesia \\ ${ }^{3}$ Department of Biology, Faculty of Science and Mathematics, Diponegoro University, Semarang - Indonesia
}

\begin{abstract}
Mangrove vegetation has a very complex function for human life now and in the future. Therefore protecting mangrove areas by preventing damage and reforesting in mangrove areas that have improved degradation must continue. The purpose of this study is to identify changes in mangrove areas for five years, as well as their impact. A literature review of previous research studies used to assess the impact of a decrease in the mangrove area, along with conservation strategies. The results showed that the degradation of mangroves for land conversion can result in decreased carbon stocks in sediments, changes in abiotic conditions in the media, a decrease in the number of fish catches, the occurrence of abrasion and a decrease infauna of the Mollusca group association. Integrated coastal management should pay attention to the sectoral dimension, dimensions of science and ecological dimensions.
\end{abstract}

Keywords: The extent changes; mangrove; Pati Regency; Study of literature.

\section{Introduction}

Mangrove Ecosystem has an important role as a supporter of life in coastal areas which are of ecological function as a provider of nutrients for marine life, the breeding and care (nursery grounds) a wide variety of organisms that live in the open sea, prevention of the occurrence of coastal erosion, breakwaters, carbon sinks, and others [1]. The existence and condition of mangrove ecosystems are more critical with increasing population and decreasing awareness of the coastal environment. As in several regions in Indonesia degradation of mangrove forests in the form of conversion into residential land, ponds, and others. According to Kusmana et al. [2], the causes of the degradation of mangrove ecosystems include: (1). The transformation/conversion of mangroves to ignore the environment, (2). Pollution, such as oil, heavy metals, and (3) Illegal logging.

Conversion of mangrove land into ponds can cause loss of ecosystem functions, besides it can also cause abrasion, reduced fish catches, the intrusion of seawater, lowering the amount of carbon storage and so on, Activities such as the addition of extensive ponds, mangrove logging is a major cause of mangrove forest destruction in Indonesia. Likewise in Pati regency, in 2013 occurred mangrove land conversion (conversion) into ponds that occur on the north coast (the District Tayu) Pati Regency [3].

Pati regency, which is located east of the city of Semarang with a distance of $\pm 80 \mathrm{~km}$ on the geographical position $110^{\circ} 50^{\prime}-111^{0} 15^{\prime}$ east longitude and $6^{0} 25^{\prime}-7^{0}$ $00^{\prime}$ latitude, and has a long coastline $\pm 60 \mathrm{~km}$. The beach is located in the coastal district seven, namely Dukuhseti, Tayu, Margoyoso, Trangkil, Wedarijaksa, Juwana, and Batangan. Growth of mangroves on the north coast Pati as presented in Table 1 below.

Table 1. Mangrove extents in Pati Regency

\begin{tabular}{|l|l|l|l|l|l|}
\hline \multirow{2}{*}{ locations } & \multicolumn{5}{|c|}{ Year (Ha) } \\
\cline { 2 - 6 } & $\mathbf{2 0 1 1}$ & $\mathbf{2 0 1 2}$ & $\mathbf{2 0 1 3}$ & $\mathbf{2 0 1 4}$ & $\mathbf{2 0 1 5}$ \\
\hline Batangan & 26.00 & 26.00 & 32.23 & 32.23 & 32.23 \\
\hline Juwana & 8.00 & 8.00 & 39.14 & 39.14 & 39.14 \\
\hline Wedarijaksa & 34.00 & 34.00 & 20.78 & 20.78 & 20.78 \\
\hline Trangkil & 35.20 & 35.20 & 21.75 & 21.75 & 21.75 \\
\hline Margoyoso & 7.00 & 5.88 & 5.89 & 5.89 & 5.89 \\
\hline Tayu & 60,50 & 22.14 & 2,14 & 2,14 & 22.14 \\
\hline Dukuhseti & 63.00 & 20.71 & 20.71 & 20.71 & 20.71 \\
\hline total & $\mathbf{2 3 3 . 7 0}$ & $\mathbf{1 5 1 . 9 3}$ & $\mathbf{1 4 2 . 6 4}$ & $\mathbf{1 4 2 . 6 4}$ & $\mathbf{1 6 2 . 6 4}$ \\
\hline
\end{tabular}

Source: [4]

Based on the table above, there was a change in the mangrove area from 2011 to 2015 , especially in Tayu Subdistrict, from an area of 60.50 hectares in 2011 to 22.14 hectares in 2015. This condition reflects the

\footnotetext{
* Corresponding author: achmadnurstp $@$ gmail.com
} 
degradation of mangrove land which will certainly reduce the quality of the coastal environment. Some previous studies have proven this, such as [5], explains that the decreasing area of mangrove land will affect the nature of the sediment and reduce the ability to store carbon. As is known that deforestation of mangrove forests can cause carbon emissions and reduce carbon absorption [6]. carbon emissions with other greenhouse gases $\left(\mathrm{CH}_{4}, \mathrm{~N}_{2} \mathrm{O}\right)$ tend to have become the dominant cause of climate change [7]. The clearing of mangrove ecosystems is always followed by a decrease in fish and shrimp catches in the surrounding coastal waters, including mangrove clearing for aquaculture [8]. The same is reported [9] that along with the decline in mangrove land the number of fish catches has decreased. Therefore, poor land use and management of coastal environments can reduce/degrade the environment.

The concept of environmentally friendly coastal management is needed to improve its quality to create and maintain a sustainable coastal area, given the importance of the coast, especially the mangrove ecosystem as the world's lungs, where the average mangrove forest/mangrove is able to store 3-4 times more carbon than tropical forests [10]. Therefore, this study examines the impact of land-use changes in the area of mangroves by mangroves, along with mitigation strategy management.

\section{Literature Review}

\subsection{Mangrove Conversion into Ponds}

Land conversion is a change of some or all of the land area of the previous function into another function, which can have negative impacts on the environment [11]. Likewise, changes mangrove land into land ponds, also known as a land conversion because the change of land function as mangrove ecosystems, changed into land fishery ponds. Mangrove land conversion into other functions such as housing, agriculture, fisheries, and others not only in Indonesia but also in various parts of the world. This is caused by the activities of human activity. Sources most serious threats to mangrove increasing human density. The increasing human population is concentrated on the shoreline, shifting the native vegetation. Mangrove habitat conversion for agriculture and fisheries are the main factors of mangrove loss. Other factors that have a direct impact is the mining and exploitation of wood, including logging. While the indirect impacts include factors such as changes in freshwater or tidal currents, pollution of oil exploration, and runoff from solid waste [12]. Conversion of mangrove into a pond can decrease fish production in the surrounding waters. In situations like this, the basic habitat and functions will be lost, and this loss is far greater than the value of replacement [13].

Therefore, sustainable management of mangrove ecosystems is expected to be able to overcome the socio-economic problems of the community without sacrificing ecological interests, so that the preservation of mangrove forests can be maintained, while the socioeconomic life of the community can be fulfilled [14].

\subsection{Impact of Mangrove Conversion into Ponds}

The types of impacts of conversion in utilization include [15]: (1) the impact of the conversion on the socioeconomic environment and (2) the impact of land conversion on the physical and biological environment. Socio-economic impacts, the conversion of mangroves to be associated with gains or losses and the form of value for money, changes in natural beauty, behavior, safety and health of the population, but it is very influential on employment and local revenue. So the aspects to be considered about to with concerning the socio-economic impact is a factor of employment, income level, patterns of ownership and control of natural resources, the level of facilities and infrastructure of the economy and the pattern of use of natural resources. Physical and biological impact of a decrease in the diversity, stability, and biological productivity. In other words, the physical destruction of coastal habitat has resulted in a decrease in the quality of the ecosystem [13].

Furthermore Dahuri et al. [13] explains that, some of the impacts of human activities on mangrove ecosystems, especially the activities of converting mangroves into agricultural and fishery lands include: (1) threatening the regeneration of fish and shrimp stocks in the waters due to mangrove functions as spawning ground and nursery ground (2) coastal sedimentation, (3) shoreline erosion, (4) salt intrusion, and (5) sea pollution by pollutants, where before being converted, the mangrove forest substrate can bind the pollutant.

\subsection{Environmental Impact Mitigation and Management}

Human activities, either intentionally or inadvertently have an impact on the mangrove ecosystem. Resource utilization and management of mangrove forests should be paying more attention to sustainability (sustainable). Mutual awareness between generations within the community in the management of mangrove forests into the key realization that given the mangrove is a natural resource that can be recovered [16].

The main purpose of forest management, including mangrove forests is to maintain the productivity of forest land so that the sustainability of the results is the main goal of forest management. Sustainability of productivity has two meanings, namely the continuity of growth and the sustainability of crop yields [15], then Bengen [14] states that the preservation of mangrove forests is a complex business unit to be implemented because these activities are in dire need of accommodating characteristics to the parties related both around and outside the region. Mangrove conservation activities are carried out to meet the needs of various interests. The accommodative nature will be more beneficial if the partisanship of institutions that are vulnerable to mangrove resources is given a larger portion. Therefore, what needs 
to be considered is to make the population a driving component of the preservation of mangrove forests.

Mangroves can grow quickly, if in typical conditions in tidal zones in the tropics, by forming complex structures and having high productivity. However, this ecosystem is very sensitive to factors such as water circulation, salinity, and the physicalchemical aspects of its substrate. Therefore, the conservation and utilization of mangroves depend on planning that is integrated and considers the needs of the mangrove ecosystem. Some rules in planning and managing mangroves in relation to sustainable development are as follows [13]: (1) the basis and character of the substrate of mangrove forests must be maintained, so that changes in chemical properties must be avoided, (2) natural patterns such as cycles tides, the continuity of freshwater runoff is guaranteed, (3) natural temporal and spatial patterns of surface salinity and groundwater must be maintained. Taking and reducing groundwater must pay attention to the salinity balance of the coastal environment, (4) the balance of land between erosion, accretion and sedimentation also needs to be considered, (5) the maximum limits on the utilization of the results of mangrove ecosystems also need to be considered the carrying capacity and capacity. This utilization is based on solid planning to ensure ecosystem sustainability, (6) in areas at risk of being exposed to waste, especially oil waste, must have mitigation plans, and (7) all activities that result in the reduction of mangrove land as much as possible.

\section{Methodology}

This study is descriptive, which according to [17], is a study that is intended to gather information about the status of a symptom that exists, with a purpose [18] to create a description, picture or painting in a systematic, factual and accurate. The methods used are literature studies, by identifying the impact of the conversion is based on research that has past, to get the mangrove ecosystem conservation strategies based on the study of literature.

According to Hadi [19], for descriptive data types, the analysis is qualitative with an approach to building a theory based on the data from which the research is conducted. These stages can be summarized with steps of description, explanation, and interpretation.

Descriptive research aims to collect actual information in detail that depicts existing symptoms, identifies problems, examines prevailing conditions and practices, makes comparisons or evaluations, determines the things others do in dealing with the same problem, and learns from their experience to determine plans and decisions in the future [20]

\section{Result and Discussions}

Based on data from the Central Statistics Agency Pati District over 5 years (2011-2015), it is known to occur changes in the area of mangrove significant in Pati regency. Especially on the north coast, starting from District Wedarijaksa, District Trangkil, District Margoyoso, District Tayu and District Dukuhseti. For the District Wedarijaksa occurred changes in the area of 34 hectares in 2011 to 20.78 hectares from 2013 to 2015 . The District of Trangkil of the area of 35.20 hectares in 2011 to 21.75 hectares from 2013 to 2015. District of Margoyoso experiencing changes in the area of 7 hectares to 5.88 hectares by 2015. To subdistrict Tayu change extents quite varied, ranging area of 60.5 hectares in 2011 to 22.14 hectares in 2012 , to fall to 2.14 hectares in 2013 to 2014 , and increased again to 22 ,

Referring to the results of the study [5], the conversion of mangroves into the pond will affect the ability to store carbon in the sediment. The results show that mangroves have experienced a conversion value $\mathrm{C}$ percentage $(\%)$, density $\mathrm{C}(\mathrm{mg} \mathrm{cm}-3)$ and carbon storage (Mgha-1) is lower than the natural location. Carbon percentage value range, density and carbon storage at the rehabilitation area respectively amounted to 1.11 to $2.25 \%, 0.01$ to $0.02 \mathrm{mg}$ cm-3 and from 94.92 to $265.26 \mathrm{Mgha}-1$, while for a natural area in the range of 12.54 to $17.14 \%$, from 0.07 to $0.09 \mathrm{mg} \mathrm{cm}-3$ and 427.54 to $606.92 \mathrm{Mgha}-1$. The results showed that the land conversion of mangrove ecosystem carbon storage capacity. Mangrove sediment conditions on land are also more stable in maintaining and stabilizing changes in the environment than non-mangrove land [21]. Conversion of mangroves into shrimp ponds in the Mahakam Delta resulted in the loss of carbon equivalent to 226 years of accumulation of soil carbon in a natural mangrove forest [22].

Change conditions due to the conversion of mangrove ecosystems were also reported by Sunarto and Tandjung [11], wherein the temperature, $\mathrm{pH}$ and salinity both water and soil significantly different between mangrove conversion and a natural mangrove. The water temperature on the conversion of mangroves for $30,00^{\circ} \mathrm{C}$, compared $31,17^{\circ} \mathrm{C}$ on natural mangrove during high tide, whereas at low- temperature conversion of mangrove $28,67^{\circ} \mathrm{C} 26,33^{\circ} \mathrm{C}$ value. Likewise, the ground temperature was significantly different between the condition of converting mangrove unspoiled. At high tide, salinity at the rate $42.58 \%$ versus $39.42 \%$ in the natural conditions. And at low tide, salinity in mangrove area Converted at the rate $36.28 \%$ versus $34.02 \%$ in the natural area. When tidal conditions, the $\mathrm{pH}$ significantly different from the natural mangrove condition, while not significantly different at low tide, but still within the tolerance level. In general the temperature parameter,

Mangrove forest linkages with a total production of fish catches, related to the function of mangroves as a spawning ground and keep the fish, so that if the area decreases the amount of fish caught also decreased. As the results of the study [9], the total fisheries production in the northern coastal of Pati Regency (Tayu and Dukuhseti) in 2011 amounted to $1.374,98$ Tons, fell to $1,077,17$ tons in 2012 , fell again to 968.65 tons in 2013 , and amounted to 905.28 tons in 2014 , then rose to 1034.17 tons in 2015 . this indicates that the mangrove changes affecting fish catches.

One of the physical functions of mangrove forests is to protect the coast from abrasion and to hold sediments 
periodically until new land is formed [23]. The results of the study [24] showed that where there was a change in the coastline on the coast of the Cirebon Regency which showed accretion by the sedimentation process. This accretion occurred in 4 sub-districts, where efforts have been made to rehabilitate mangroves in the subdistrict. Whereas in the other 3 Subdistricts there was an abrasion, where the length of the mangrove green line has decreased, turning into a pond.

The ecological function of mangrove ecosystems as spawning sites, fish farms, sources of nutrients, a shelter for juveniles and fish larvae must be preserved. One thing that can be done is the use of remote sensing technology to monitor changes in mangrove land. As the results of research [25], using Landsat-8 imagery to analyze vegetation index (NDVI) and the relationship of mangrove density with its associated fauna, the results show that the denser the mangroves, the more abundant the fauna. The highest density of mangroves in the family Rhizophorzceae, with the predominance of fauna associated with the gastropod class of the Terebralia sulcata species, in the Bivalvia class the highest abundance was in the Isognomon ephippium type and the crustacean class the highest abundance of the Scylla spp. This correlation relationship is positive, where mangrove with sparse density $(<1000$ trees / ha) then the density of its fauna (0-5789,127 individuals / ha), mangrove with medium density (1000-1500 trees / ha) then the faunal density $(5789,127-13177.13$ individuals / Ha) and solid density ( $\geq 1500$ trees / Ha), then the density of the fauna ( $\geq 13177.13$ individuals / Ha). This happens because of the availability of abundant food sources in these mangroves.

Integrated coastal zone management is a coastal management approach involving two or more ecosystems, resources and utilization activities (development) in an integrated manner to achieve sustainable development of coastal areas. In this context, the integration contains three dimensions: sectoral, science, and ecological relevance [13]. By Mappanganro [26], the result of changes in cotton area of mangrove forest in the village of Keera caused by the activity of the community is that feeling of mangrove forests and then converted into a pond, overexploitation, as well as law enforcement entry, then compiled strategic direction mangrove rehabilitation based on the results of SWOT analysis set 8 strategies, namely: (1) Restore the mangrove function in accordance with the spatial pattern of ecological rehabilitation; (2) provision of means of mangrove aquaculture (breeding and seeding) managed directly by the public; (3) improving the quality of human resources surrounding communities of mangrove ecosystems; (4) Increase the basic tasks of society watchdog groups through operational assistance; (5) enforcement and institutional capacity building; (6) The replanting of mangrove coastal areas identified are severely damaged by abrasion; (7) increased community participation and other stakeholders in the rehabilitation of mangrove ecosystems; (8) the development of pond-based systems (Silvofishery) is good. (6) The replanting of mangrove coastal areas identified are severely damaged by abrasion; (7) increased community participation and other stakeholders in the rehabilitation of mangrove ecosystems; (8) the development of pond-based systems (Silvofishery) is good. (6) The replanting of mangrove coastal areas identified are severely damaged by abrasion; (7) increased community participation and other stakeholders in the rehabilitation of mangrove ecosystems; (8) the development of pond-based systems (Silvofishery) is good.

\section{Conclusion}

Mangrove forest area in the Pati Regency decreased during the 5 years from 2011 to 2015 amounted to 91.06 hectares. Appropriate literature review, a decrease in land cover will affect coastal environmental conditions, such as the decrease in carbon stocks, influencing chemical physics parameters, influencing shoreline changes, influencing the abundance of fauna associations to affecting fish catches in the coastal region. Integrated environmental management based on sustainable principles should be applied, so that the condition can be restored remembering mangrove resources, including resources that can be recovered.

\section{References}

1. M.S.Tarigan, J. Makara Sains 2, 108-112 (2008)

2. C. Kusmana, S. Wilarso, I. Hilman, P. Pamoengkas, C. Wibowo, T. Tiryana, A. Triswanto, Yunasfi, Hamzah, Tek. Rehab. Mangrove (2003)

3. Koranmuria.com, Htn Mangrove Tayu Brbh Jd Tmbk, Nlyn Gerah, http://koranmuria.com diakses 18 Desember (2018)

4. Badan Pusat Statistik Kab. Pati, Pati Dalam Angka, (2016)

5. T.L. Kepel, R.N. Afiati, Y.P. Rahayu, N.S. Adi, JKN 13, 145-153 (2018)

6. D.M. Alongi, Annu. Rev. Mar. Sci. 6, 195-219 (2014)

7. IPCC, Climate Change Summary for Policy makers, Intergovern Panel on Climate Change, (2014)

8. P. Martosubroto, M. Naamin, MRI 18, 81-86 (1977)

9. H.T. Prayitno, J. Litbang, 13, 93-104 (2017)

10. D.C. Donato, J.B. Kauffman, D. Murdiyarso, S. Kurnianto, M. Stidham, J. Nat. Geosci. 4, 293-297 (2011)

11. M.A. Sunarto, D. Tandjung, Mjlh. Geografi. Ind. 23, 18-39 (2009)

12. S.S. Romañacha, D.L. DeAngelis, H.L. Koh, Y. Li, S.Y. Teh, R.S.R. Barizan, L. Zhai, J. OCM. 154, 7282 (2018)

13. R. Dahuri, J. Rais, S.P. Ginting, M.J. Sitepu, Pengelolaan Sumberdaya Wilayah Pesisir dan Lautan Secara Terpadu, 5 (2013)

14. D.G. Bengen, Pedm.Tekns.Pengnl. dan Pengl. Ekstm. Mngrove (2001)

15. K. Rusdianti, S.Sunito, JSP 6, 1-17 (2012) 
16. N. Harahab. Penilain. Ekonomi Ekosistem Hutan Mangrove dan Aplikasinya dalam Perencanaan Wilayah. Pesisir. I, (2010)

17. S. Arikunto, Manajemen Penelitian (2005)

18. M. Nazir, Metode Penelitian (2003)

19. S.P. Hadi, Metodologi Penelitian Lingkungan Bidang Sosial (2017)

20. N, Hartati, Statistika untuk Analisis Data Penelitian, I, 68 (2017)

21. E.C. Rodríguez, I.L. Luna, J.P. Hernández, JRSMS 17, 38-46 (2018)

22. V.B. Arifanti, J.B. Kauffman, D. Hadriyanto, D. Murdiyarso, R. Diana, JFEM 432, 17-29 (2019)

23. C, Saparinto. Pendayagunaan Ekosistem Mangrove, I, 2-3 (2007)

24. P. Raharjo, D. Setiady, S. Zallesa, E. Putri, JGK 13, 9-24 (2015)

25. M. Christy, A. Saru, M.A. Amran, Hubungan Kerapatan Mangrove Dengan Fauna Asosiasi di Pulau Panikkiang Dengan Menggunakan Citra Landsat-8, J. ST. 18, 183-190 (2018)

26. F. Mappanganro, D. Asbar, JPTP 4 (2018) 